\title{
Legal Consequence on Certificate of Property Publishing By the National Land Agency for Unauthorized Purchase
}

\author{
Ari Setyo Aji ${ }^{1}$ and Umar Ma'ruf ${ }^{2}$
}

Abstract. The purpose of this study was to analyze: 1)To know and explain about factors which causes of invalidity of buying and selling land. 2) To determine the position of court cases 06 / Pdt.G / 2017 / PN.Btg and legal considerations the judges in deciding the case a quo. 3) To know and analyze the legal consequences of the issuance of certificates of property rights by the National pertananahan body over the unauthorized purchase has no legal force and is against the law in a civil case No.06 / Pdt.G / 20017 / PN.Btg, The approach method in this research is the socio-juridical. The data used are primary and secondary data obtained through interviews and literature, while the data analysis conducted Qualitative Analysis Results of the research can be concluded: 1) that the sale and purchase of land especially to land inheritance, should involve and seek approval to all heirs. 2) that the sale and purchase of land inheritance that does not involve all the heirs then selling the land becomes invalid so that Mutatis Mutandis certificate publishing rights Illegitimate and Cancel by the Law. 1) that also challenged that the plaintiff must file a lawsuit prior to the Parties involved in the process of buying and selling land inheritance, from the Seller, Buyer, PPAT, and the Land Office as a party to issue a Certificate of Rights Reserved. The solution that should PPAT and Land Office to socialize, it aims to provide insight to the public especially to the sale and purchase of land.

Keywords: Legal Consequence; Certificate; Property Publishing; Unauthorized Purchase.

\section{Introduction}

Trading activity is a common thing that we see in our daily lives. To give a brief knowledge about buying and selling assessed from the aspect of civil law.

Article 1457 of the Civil Code of buying and selling is an agreement by which one party binds himself to hand over the goods, and the other party to pay the promised price.

According to M. Yahya Harahap, Buying and selling is an agreement which means to give birth to an agreement just enough to agree and the agreement has been born at the time or the second consensus. Everything valuable object property, not just tangible objects, but all the objects. ${ }^{3}$

That to be valid a sale and purchase agreement binding the parties themselves shall qualify valid, namely: Those agreements that bind him; Ability to create an engagement; A particular subject matter; and A cause that is not prohibited.

\footnotetext{
1 Students Master of Notary Law, Sultan Agung Islamic University in Semarang email arisetyoaji49@gmail.com

${ }^{2}$ Faculty of Law UNISSULA

3 M. Yahya Harahap, 1986, Segi-Segi Hukum Perjanjian, cetakan kedua, Alumni, Bandung, p 182
} 
The first two conditions is a condition related to the subject (a subjective condition) while the last two terms are familiar object (objective requirements). An agreement containing a defect in the subject does not always make the agreement be canceled by itself, but often only memberikankemungkinan to be canceled, while the flawed agreement in terms of its object is null and void.

In selling - buying two subjects, the seller and the buyer, that each other have various obligations and various rights. Then each other in some it is the incumbent party and the other thing is the party entitled. This relates to the reciprocal nature of the contract of sale - purchase.

Subjects were either humans, must meet the general requirements to be able to perform a legal act lawfully, that must be grown, healthy mind and is not legally prohibited or diperbatasi in terms of doing. Valid legal actions. For minors, must be accompanied by a parent or guardian, for the people - people who are not healthy mind, must act in a supervisory or curatornya.

If the subject of selling - buying is the seller and the buyer, ie elements - elements that act, then the object of selling - buying is that the goods they sold or bought. To determine what the object of selling - buying goods or rights are owned. This means, that can be sold or bought it not only goods on hand, but a right to goods that are not proprietary. Terms of the object of selling - buying is feasible, if at the time of sale purchase occurs. If the goods have been destroyed completely, then the agreement null and void, while apabilabarangnya only partially destroyed, then the buyer can choose between the cancellation of the selling - buying or receiving the goods that they last section with a partial payment of the price that has been promised.

That in the implementation of buying and selling, often cause problems or pose a particular dispute to purchase land dispute and not infrequently to be resolved through the courts in order to obtain legal certainty.

Disputes that buying and selling land is a classical problem, and there is always everywhere on earth. Therefore, disputes related to land purchase always take place continuously, because every person has the interest relating to the legal acts in the form of buying and selling especially land purchase. ${ }^{4}$

Civil disputes relating to land may occur between individuals or between individuals and legal entity. Disputed diverse, both with regard to physical land data, the data juridical, or because as buying and selling legal acts on the ground. ${ }^{5}$

Civil law is a formal civil law intended to enforce the substantive civil law. This civil law ensure observance of substantive civil law. The provisions of civil law is intended to implement and maintain civil substantive legal rules that exist.

Everyone must obey the laws that have been established, one should not act in their own way, but must be based on the legal regulations that have been established and regulated in the law. If a dispute the parties can not solve with peace, then the last way that can be taken is requested settlement through a judge. How to settlement through this judge stipulated in civil law.

\footnotetext{
${ }^{4}$ Sarjita, 2005, Teknik dan Strategi Penyelesaian Sengketa Konflik, Cetakan kedua, Tugujogja Pustaka, Yogyakarta, p. 1

${ }^{5}$ Op.cit, p. 50
} 
"The process of settlement of disputes through the judge to restore the right of a person who has been harmed or disturbed, restore the atmosphere like in the original state that everyone must abide by the rules of civil law, civil law regulations so that working as it should". 6

In the court proceedings would not be separated from the role and duties of judges as law enforcement officials to investigate and adjudicate any dispute. Disputes filed in court will be processed and the judge dropped the decision. The judge's decision will lead to legal consequences, namely that if it appears a dispute about the legal relationship established by a judge's decision where the parties are bound by the verdict. The ability to bind the parties at a later date of the judge's decision that is called the power of the judge's decision (gezag van gewijsde).

The purpose of a process in court is to obtain a legally binding verdict that remain. With this ruling the relationship between the two parties to the dispute are set for ever with the intention that if it is not adhered to voluntarily imposed with the help of tools for countries (with the force of law / inkracht van gewijsde). ${ }^{7}$

With the rule of law, then everyone should obey. But in a legal relationship that happens, there is a possibility that one party does not fulfill the obligations of the other party, so that the other party feels aggrieved and what they are entitled should he could not get. To defend their rights and obligations, one should act on legislation that has been set. If the parties concerned can not resolve its own demands peacefully, then the party who feels aggrieved may request assistance to the judge for help in resolving the dispute. The aim of dispute resolution is to restore the right to judge someone who has harmed or impaired, and through the judge did anyone get the assurance of rights that must be respected by everyone so that legal certainty is completed.

Judges play an important role from the beginning to the end of the examination in court. Pursuant to Article 119 or 143 RBg HIR judge has the authority to give directions to the party who filed the lawsuit to the court with the intention that this dispute be clearly seated disputes and facilitate judges examine the dispute. In the dispute, the judge really should be freely and impartially anyone. In the trial, the judge must hear the statements of both parties with their respective evidence so the judge can find the real truth.

In the law there is the doctrine that ius curia Novit, meaning that the judge deemed to know the law. Therefore rejection check out disputed on the grounds that there is no or less clear legal rules, is not allowed. However, when dealing with the rule of law, the judge deemed to know the law and can make decisions based on science and his own beliefs. Pursuant to Article 16 paragraph (1) of Act No. 48 Of 2009 jo. Act No. 4 of 2004 on Judicial Power, the court may not refuse to examine and hear something disputes filed under the pretext that the law does not exist or is less clear, but is obliged to examine and hear.

\footnotetext{
${ }^{6}$ Abdulkadir Muhammad, 2000 , Hukum Acara Perdata Indonesia, Bandung : Citra Aditya Bakti, p. 15

${ }^{7}$ Subekti, 1989, Hukum Acara Perdata, Bandung : Bina Cipta, p. 124
} 
Based on this background, lifted the title " Legal Consequence On Certificate Of Property Publishing By The National Land Agency For Unauthorized Purchase".This study sought to answer the problem As a result of the Law of Property Rights Certificate Issuance by the National Land Agency To Purchase The Unauthorized.

Method approach used in this study is a juridical Sociological, namely In the face of the issues discussed by the regulations in force then corresponds to the realities in society. In support and complement secondary data, field research is conducted in order to obtain primary data. The primary data obtained through interviews, Specifications research is analytical descriptive. Primary data were collected by interview. Secondary data is data obtained from a review of the literature or the review of the literature or library materials related to the problem or research materials that are often referred to legal materials. Analysis of the data used in this research is the analysis of qualitative data that have been obtained from field studies and literature will be collected and systematically categorized and then analyzed qualitatively in order to obtain an overview and understanding of the systematic and comprehensive to address the problems examined.

\section{Results and Discussion}

2.1 Invalidity factor causes the buying and selling land and Positions of case No. 06 / Pdt.G / 2017 / PN.Btg

Transfer of rights to land is one of the events and / or legal actions that resulted in the transfer of land rights from the owner to another party. The switch can be intentional because of their legal actions such as buying and selling, leasing and so on, and also not accidental because the legal events such as the transition because of the inheritance.

The estate will be traded would have the consequence of the heirs namely that each heir is entitled to ownership of the land. Therefore, it should be inherited land purchase was approved by all the heirs as parties gain ownership of the land due to inheritance. Purnamasari Irma Devita, SH, M.Kn., in his book entitled Kiat-Kiat Cerdas, Mudah, dan Bijak Memahami Masalah Hukum Waris (p. 176-177). ${ }^{8}$ So when one person heirs sold the estate and there was an agreement between the seller of the land inherited by the buyer. However, once the land is sold and paid for by the buyer legally before witnesses, there are other heirs are actually entitled to the inheritance of land ownership dispute because he felt he was not included in the land sale. In other words, the heirs of the estate does not agree to the transfer of land rights to own others, so there is a dispute over the sale and purchase of the land.

Inheritance that arise because of the death, and each of the events of death, documents that must be held to hand over land rights is: death certificate or death certificate; and Certificate of Inheritance (or the establishment of religious courts about anyone heirs), determines about anyone who is entitled to inherit in advance at the 8 Irma Devita Purnamasari, 2008, Kiat-Kiat Cerdas, Mudah, dan Bijak Memahami Masalah
Hukum Waris, Kaifa 
office of the local municipality, as the basis for the process of land registration and land rights transitional process. ${ }^{9}$

An heir must request approval of other heirs if it wanted to sell the land inheritance, because the other heirs alsohas the right to the land. If someone who is entitled to the estate evokes the notion that he is the sole owner of the land, the purchase should not be considered to be held by the requirements secretly. But if there are other heirs who are also entitled to the land are not included, in the sense that there is no consent, there will be a dispute over land sales it. Appear dispute stems from complaints heir containing objections and demands of land rights legacy, to the status of land, or ownership in the hope of obtaining the completion of the administration in accordance with the applicable rules.

At the present time a lot of the sale of land which is the inheritance of the heir without the knowledge of all the heirs there. In the sense that one of these heirs are trying to master the inherited land and do not want to share with the heirs of the above. It will eventually become a problem that must be resolved through jalurPengadilan, because the parties can no longer assume resolve the issue amicably and by consensus.

One example of a dispute over the estate purchase can be found in Batang District Court No. 06 / Pdt.G / 2017 / PN.Btg, that according to the Plaintiffs that the brother of the late Alm. Sugito Bin H. Saleh Mas'ud, Testified that during his lifetime Alm. Sugito Bin $\mathrm{H}$. Saleh Mas'ud obtain the treasure legacy of parents are H. SALEH MAS'UD with the mother Khazanah form: Land and Home / Store recorded in SHM No. 423 / Ex Proyonanggan spacious $279 \mathrm{~m} 2$, registered in the name SUGITO, located in the village Proyonanggan, District of Batang, Batang.

That mr. SUGITO, died on Monday, June 01, 2012, leaving the Heirs namely: Mrs. Sudaryati (Wife of Mr. Sugito) and 6 (Six) your bladder.

That after the death of the deceased SUGITO, on May 10, 2013've done sharing deal on Heritage in the form of land and building recorded in SHM No. 423 / Ex Proyonanggan spacious $279 \mathrm{~m} 2$, registered in the name SUGITO, located in the village Proyonanggan, District of Batang, Batang, as mentioned in the Heritage Fatwa by Team Heritage Fatwa Tabliq Assembly Branch Chairman of Muhammadiyah Pekajangan Pekalongan district who have attended and agreed upon and signed by all heirs, the wife of the late Mr. Sugito and 6 (six) siblings of Mr. Sugito

That therefore it is the wife of the late Sugito with 6 (six) siblings have the same inheritance rights on Heritage deceased SUGITO the form of land and building recorded in SHM No. 423 / Ex Proyonanggan spacious 279 m2, registered in the name SUGITO, located in the village Proyonanggan, District of Batang, Batang

Whereas the inheritance sharing agreements, it appeared in about February 2017, the house listed in the SHM No. 423 / Ex Proyonanggan spacious 279 m2, on behalf of SUGITO been sold by the wife of the late Sugito unbeknownst Heirs who else is 6 (siblings Alm Sugito sold under way to do behind the name in advance of the name Sugito behind the name on behalf Sudaryati, so act Alm Sugito's wife is obviously very

\footnotetext{
${ }^{9}$ Adrian Sutedi, 2006, Peralihan Hak Atas Tanah dan Pendaftarannya, Sinar Grafika, Jakarta, p.102
} 
detrimental to six (6) siblings who are also entitled to the inheritance of the Alm Sugito.

Legal considerations that the judges in the District Court in the Terminate Trunk Case No. 06 / Pdt.G / 2017 / PN.Btg namely thatland and houses located in Proyonanggan Central with an area $279 \mathrm{~m} 2$ is registered in the name SUGITO siblings of the Plaintiffs, the more land and buildings are relics of the parents Sugito together with the Plaintiff as siblings are entitled to the land and the building, thus Wife Alm Sugito who have made the sale of land and building homes recorded in the SHM 423 / Ex. Central Proyonanggan with an area $279 \mathrm{~m} 2$ on behalf SUGITO without the consent of siblings is an act against the law so that the sale and purchase of the land the house is recorded in SHM No. 423 / Ex. Central Proyonanggan with an area $279 \mathrm{~m} 2$ on behalf SUGITO is Unauthorized, not having the force of law and is against the law. ${ }^{10}$

\subsection{As a result of the issuance of the certificate of property rights laws by the National Land Agency over the unauthorized trading in a civil case No.06 / Pdt.G / 20017 / PN.Btg}

In terms of buying and selling land, the sale and purchase of legal acts carried out by the Land Deed Official certificate ( "PPAT"), as contained in Article 2 in Government Regulation No. 37 of 1998 Concerning the Rules of Land Deed Official Position and Article 95 of the Regulation of the State Minister of Agrarian Affairs / Head of National Land Agency No. 3 of 1997 on the Implementation Provisions of Government Regulation No. 24 of 1997 on Land Registration ( "Permen on Agrarian 3/1997"). The PPAT Deed is evidence of transfer of land rights for the sale and purchase. ${ }^{11}$

That the sale and purchase of land, especially against the estate must be approved by all the heirs as a party to obtain ownership of the land due to inheritance, and if there is no consent of the heirs, then the land was sold by people who are not entitled to sell (because of the current holds the property rights to the land that is the heir).

that by Article 1471Code of Civil law( "Civil Code"), Which speaks of the purchase (basically the same as the buying and selling land buying and selling in general), which implicitly requires that the seller must be the owner of the goods sold:

"Sale and purchase of goods of others is void and can provide the basis for a buyer to demand reimbursement of costs, damages and interest, if he does not know that the item belongs to someone else ".12

That if it turns out the seller is a person who is not entitled to sell the land, especially land inheritance, then the heirs who feel that their rights are violated because their land is sold without their consent, to carry out a civil action on the basis of tort, as stipulated in Article 1365 of the Civil Code, which reads:

"Each unlawful act and bring harm to others, require a person to incur losses because mistakes to replace those losses."

\footnotetext{
${ }^{10}$ Interview with ARIF NS, SH MH Advocates as Attorney Plaintiffs

${ }^{11}$ Government Regulation No. 24 of 1997 on Land Registration

12 Code of Civil law
} 
Therefore, based on Article 1471 Civil Code above, the purchase is canceled. With the cancellation of the sale and purchase, the sale and purchase shall be deemed to have never existed, and each party is returned to its original state before the events of "trade", which is where the land ownership remains with the heirs, it is also in accordance with the case No. 06 / Pdt.G / 2017 / PN.Btg which states that:

"action DEFENDANT I who have made sales of land and building homes recorded in SHM No. 423 / Ex Proyonanggan spacious 279 m2, to DEFENDANT II (GIAN MEI DIAN) before Notari / PPAT KHUMAIDI SH.Mkn (Defendant III) to return the name to the name of DEFENDANT II made the BPN Batang (Defendant IV) is UNAUTHORIZED, HAVE NO POWER ON LAW and AGAINST THE LAW the nature and legal act of buying and selling up to return the name of Land Houses SHM No. 423 / Ex Proyonanggan spacious $279 \mathrm{~m} 2$ of SUGITO name to the name of the Defendant II (GIAN MEI DIAN) is Cancel Demi Law and Punish Defendant IV to conduct on the ground behind the house building name SHM No. 423 / Ex. Proyonanggan spacious $279 \mathrm{~m}^{2}$ of name DEFENDANT II (GIAN MEI DIAN) back to the original name that is SUGITO "13

\section{Closing}

\subsection{Conclusion}

- That the procedure of selling the estate in accordance with the provisions of the Agrarian Law, namely: land purchase legacy must be approved heirs as parties obtain ownership rights over land due to inheritance, and had made an agreement under hand or under deed that all heirs agreed to sell the land, under the terms of a special power of attorney, letters of proof as heir, the death certificate of the subdistrict head, village head, hospitals or authorities, proof of identity of heir;

- The legal consequences to buying and selling land unknown heritage other heirs null and void and can be canceled (in violation of the terms of subjective and objective) for the sale and purchase has brought losses to the other heirs;

- Legal considerations in Batang District Court's Decision No. 06 / Pdt.G / 2017, namely that the actions of Sellers to sell the land the house is recorded in SHM No., 423 / Ex Proyonanggan spacious 279 m2 SUGITO name is Unauthorized, not legally is against the law so that, mutatis mutandis, the issuance of certificates Properties by the National Land Office Batang is null and void and ordered the National Land Office Batang to perform under the name certificate property rights over the name of the original

\subsection{Suggestion}

- That the legal actions in the form of buying and selling land especially against the estate should be done in accordance with applicable regulations, which in selling the land must be utilized in the consent and approval of all heirs

\footnotetext{
${ }^{13} \mathrm{~A}$ copy of the Decision on Case No. 06 / Pdt.G / 2017 / PN.Btg
} 
- Whereas the PPAT as the official who made the deed of sale and the National Land Agency should be more rigorous in issuing certificates in particular property rights to land inheritance, so do not bring the dispute later

\section{Bibliography}

\section{Books}

[1] A copy of the Decision on Case No. 06 / Pdt.G / 2017 / PN.Btg

[2] Abdulkadir Muhammad, 2000 , Hukum Acara Perdata Indonesia, Bandung : Citra Aditya Bakti,

[3] Adrian Sutedi, 2006, Peralihan Hak Atas Tanah dan Pendaftarannya, , Sinar Grafika, Jakarta

[4] M. Yahya Harahap, 1986, Segi-Segi Hukum Perjanjian, cetakan kedua, Alumni, Bandung

[5] Sarjita, 2005, Teknik dan Strategi Penyelesaian Sengketa Konflik, Cetakan kedua, Tugujogja Pustaka, Yogyakarta

[6] Subekti, 1989, Hukum Acara Perdata, Bandung : Bina Cipta

\section{Legislation}

[1] Code of Civil law

[2] Government Regulation No. 24 of 1997 on Land Registration 